JERZY KORCZAK

ORCID: 0000-0003-1104-4837

Uniwersytet Wrocławski

jerzy.korczak@uwr.edu.pl

\title{
Dyspersja administracji jako przyczyna niepomijalności administracji publicznej
}

\begin{abstract}
Abstrakt: W artykule prezentowany jest pogląd o nieograniczoności rozrostu zjawiska administracyjnego pod wpływem przemian cywilizacyjnych. Przedstawione zostaną poszczególne jego przyczyny i czynniki kształtujące, w wyniku których administracja otrzymuje nowe zadania do wykonania. W konsekwencji rozrostu zadań następuje rozrost jej struktur, ale też przekształcenia w zakresie form działania. Jak zostanie wykazane, proces dyspersji ma charakter obiektywny i nie jest wynikiem działania samej administracji, lecz czynników zewnętrznych.
\end{abstract}

Słowa kluczowe: administracja publiczna, zjawisko administracyjne, dyspersja, pogranicze prawa administracyjnego.

\section{Wstęp}

Zorganizowana w 2019 roku konferencja naukowa z okazji jubileuszu pięćdziesiąciolecia Instytutu Nauk Administracyjnych Uniwersytetu Wrocławskiego przyjęła za motyw przewodni szczególną cechę administracji, jaką jest jej niepomijalność - nie tylko w świetle tradycyjnej koncepcji trójpodziału władz, gdzie w sposób niekwestionowany wypełniła w całości funkcję władzy wykonawczej, ale też w kontekście współczesnych debat politycznych nad modelem administracji i jej znaczeniem dla współczesnego państwa, w których formułowane są stanowiska o przerostach administracyjnej ingerencji w życie człowieka, o zbyt rozbudowanych strukturach i procedurach, a w ich następstwie o nadmiernej liczbie zatrudnionych w niej osób. Projektodawcy tytułu konferencji, lecz także uczestnicy, zarówno referenci, jak i dyskutanci, poszukiwali wielu uzasadnień hipotezy o niepomijalności administracji bez względu na rozwiązania ustrojowe państwa 
oraz głoszone poglądy o możliwości tworzenia współczesnych i przyszłych form organizacji życia społecznego ograniczających czy wręcz eliminujących administrację publiczną.

W artykule zostanie zaprezentowany pogląd o naturalnym pochodzeniu administracji jako zjawiska kulturowego wynikającego z działania człowieka, a zatem o podłożu antropologicznym, którego autorem był Franciszek Longchamps, współtwórca wrocławskiej szkoły administratywistycznej i projektodawca założeń utworzenia Instytutu Nauk Administracyjnych w 1969 roku. Pogląd ten zostanie wzbogacony o konkluzje płynące z rozważań Jana Bocia, ucznia Franciszka Longchampsa i kontynuatora jego badań nad zjawiskiem administracji, o nieustannym rozwoju funkcji administracji wynikających z rozwoju cywilizacyjnego.

W naukach biologicznych i naukach ścisłych do opisania procesów rozrastania się badanych zjawisk użyto terminu „dyspersja”" Tym samym tytułowa teza konferencji o niepomijalności administracji publicznej zyskuje szczególne uzasadnienie, albowiem nieustanny rozrost zjawisk administracyjnych, powodowany rozwojem cywilizacji ludzkiej, prowadzi do stanu, w którym nie da się ich pominąć bez zaprzeczenia jej roli we współczesnej cywilizacji ludzkiej bez względu na stopień i formę jej organizacji.

\section{Pojęcie zjawiska administracyjnego}

Kiedy Franciszek Longchamps rozpoczynał prace nad swoją rozprawą habilitacyjną, był człowiekiem jeszcze bardzo młodym (miał ponad 30 lat), a zarazem wyjątkowo doświadczonym przeżyciami wojennymi i pobytem w hadamarskim, a następnie murnauowskim oflagu. Ta metrykalna młodość nie szła jednak w parze z jego wielkim rozwojem intelektualnym ${ }^{2}$, którego nie zahamowała nawet obozowa rzeczywistość, skoro współorganizował kursy prawnicze i prowadził wykłady

1 Termin jest wieloznaczny i używany w poszczególnych dziedzinach i dyscyplinach z różnym zastosowaniem. Na ogół jest wiązany z rozproszeniem (łac. dispersio — rozproszenie) w rozumieniu rozprzestrzenienia się, na przykład w biologii organizmów w stosunku do obszaru pierwotnie zajętego przez populację; w chemii jako przenikanie się dwóch substancji, przy czym jedna z nich ulega rozproszeniu w drugiej, tworząc tak zwane układy koloidalne; w fizyce jako rozchodzenie się fal (elekromagnetycznych lub akustycznych) w określonym środowisku; w matematyce jako różnicowanie elementów populacji statystycznej w kontekście ustalenia marginesu błędu wyniku badania; w ekonomii wiąże się głównie z rozproszeniem cen na rynku w kontekście procesów kształtowania się ceny maksymalnej i minimalnej; zob. T. Galewski, Czynniki wptywające na dyspersję cen na e-rynkach, „Konsumpcja i Rozwój” 2015, nr 1 (10), s 33-43. Pojawia się też jako synonim nieuregulowanego procesu rozrostu zjawiska z negatywnymi jego następstwami; zob. np. S. Ciapała, T. Zielonka, J. Kmiecik-Wróbel, Metody zapobiegania nielegalnej dyspersji turystów i zwiazanej z nia erozji gleby w Tatrzańskim Parku Narodowym, „Folia Turistica. Turystyka i ekologia” 2010, nr 22, s. 67-90.

2 Zapowiadała to już rozprawa doktorska Ograniczenie prawa własności w polskim prawie administracyjnym obroniona pod opieką naukową prof. Zbigniewa Pazdro na Wydziale Prawa Uni- 
z nauk prawnych dla osadzonych podobnie jak on polskich oficerów. Doświadczenia wojenne prowadziły go jednak do dosyć osobliwych konsekwencji naukowych, a mianowicie do kwestionowania głoszonych przed wojną poglądów na istotę administracji i nauk o niej, skoro administracja państwa faszystowskiego, mimo że spełniającego doktrynalną definicję państwa prawnego, nie odpowiadała doktrynalnemu opisowi administracji państwa prawnego, a administracje innych państw europejskich, mimo spełniania formalnie tych cech, nie były w stanie zapobiec jej ekspansji i zbrodniczym działaniom ${ }^{3}$.

To właśnie od rewizji poglądów na administrację i jej naukowy opis Franciszek Longchamps rozpoczął rozważania w swojej rozprawie, dochodząc do wniosków, że dotychczasowe opisy administracji jako przedmiotu badań nauk administracyjnych są zawodne i niewystarczające. Nie dotyczyło to tylko tych prezentujących nurt tak zwanych negatywnych definicji administracji jako teorii „wielkiej reszty” po wydzieleniu funkcji prawodawczej i sądowniczej, bo, jak dowodził, administracja XX wieku — a prowadził przecież swoje badania w państwie zwasalizowanym przez Związek Sowiecki z jego doktryną jedynowładztwa - była równie wyposażona w funkcje prawodawcze, choć podustawowe, jak klasyczne organy prawodawcze ${ }^{4}$, jak i quasi-sądownicze, gdy pisał o organach administracyjnych wymierzających kary ${ }^{5}$. Dotyczyło to także tak zwanych pozytywnych definicji, które jego zdaniem jak dotąd nie były w stanie ująć wszystkich funkcji i zadań administracji, dlatego krytycznie oceniał dokonania doktryny niemieckiej, szwajcarskiej i francuskiej, a wreszcie i polskiej ${ }^{6}$.

Inspiracją kierunku myślowego Franciszka Longchampsa były bez wątpienia poglądy spotykane już w pracach okresu międzywojennego, jak chociażby Władysława Leopolda Jaworskiego, który zwracał uwagę, że administracja ma charakter nie tylko prawny, ale też gospodarczy, psychologiczny i etyczny, innymi słowy uznawał wieloaspektowość rzeczywistości administracyjnej ${ }^{7}$, jednak jak podkreślał — „nie zostały one doprowadzone do takiego stopnia uściślenia, by je można bezpośrednio przejąć i posługiwać się nimi”. Zauważał też, że „formułowanie tych stanowisk przedsiębrane zazwyczaj było w innych celach $[\ldots]$

wersytetu im. Jana Kazimierza we Lwowie w 1938 roku, którą oceniano jako przełomową i dowodzącą dużej dojrzałości naukowej.

${ }^{3}$ F. Longchamps (Założenia nauki administracji, Wrocław 1991, s. 116) pisał o niemieckiej administracji okupacyjnej w Polsce, że „była ogromnym systemem eksploatacji gospodarczej i niszczenia biologicznego, umysłowego i moralnego polskości”, przywołując publikację Stefana Rybczyńskiego Kierownictwo administracji niemieckiej jako organizacja przestępcza w GG, „Demokratyczny Przegląd Prawniczy" 3, 1947, nr 4, s. 35-39.

4 Por. F. Longchamps, op. cit., s. 66-69.

5 O względności rozgraniczenia funkcji sądowniczej i administracyjnej zob. ibidem, s. 50, $133-147$.

${ }^{6}$ Zob. ibidem, rozdział I, zwłaszcza s. $69-70$ oraz s. 127-128.

${ }^{7}$ Ibidem s. 63-65 i przywoływane poglądy W.L. Jaworskiego, Nauka prawa administracyjnego. Zagadnienia ogólne, Warszawa 1924. 
pomocniczych" ${ }^{8}$. Toteż podjął własną próbę — absolutnie oryginalną — opisu administracji jako zjawiska rzeczywistego, a nie wyłącznie konstruktu myślowego, postrzeganego przez „wydarzenie, zjawisko przestrzenno-czasowe”, które nosi cechy pomyślanego porządku'. Tak wyodrębnione wydarzenie, czy też zjawisko przestrzenno-czasowe, jest zarazem przejawem działania człowieka, bo dla Franciszka Longchampsa administracja przejawiała się wyłącznie w działaniu ludzi (na przykład urzędnika czy piastuna organu lub członka organu kolegialnego), a nie funkcjonowaniu bezosobowego organu ${ }^{10}$. Określał je mianem działania kulturowego, albowiem każde takie działanie wprowadza zmianę w rzeczywistości, która otacza człowieka, a zmiana ta daje się oznaczyć przez stosunek do wartości ujmowanych jako obiektywy społeczne występujące w danym społeczeństwie i będące podstawą dokonywanych przez nie ocen (akceptacji i dezakceptacji) ${ }^{11}$.

Spośród wszelkich działań kulturowych człowieka wskazywał jednak jako zjawiska administracyjne wyłącznie te podejmowane na stanowisku publicznym rozumianym jako pozycja wobec innych, charakteryzująca się przewagą lub wyłącznością w zakresie używania pewnych środków, przewidzianą przede wszystkim prawem, które wyznacza granice przewagi, rodzaj środków oraz rodzaj i zakres ochrony tej pozycji. Zwracał przy tym co prawda uwagę, że stanowisko publiczne może być niekiedy wyznaczone stanem faktycznym, aczkolwiek nie traktował go jako kategorii stałej ${ }^{12}$. Ponadto stanowiska publiczne muszą być ujęte $\mathrm{w}$ jakimś układzie administracyjnym wyznaczonym podziałem pracy, zatem wyłączał działania w sferze prywatnej i działania dorywcze oraz związane $\mathrm{z}$ funkcją rządzenia w państwie. Tym samym układ funkcjonuje w rzeczywistości znakowanej, wyznaczony czynnikami koniecznościowymi wynikającymi z pewnych praw natury i praw społecznych, czynnikami powinnościowymi wynikającymi z norm prawnych, norm technicznych czy warunków ekonomicznych działania, a wreszcie czynnikami dowolnościowymi mającymi swe źródło w pewnym marginesie luzu decyzyjnego, jaki prawo pozostawia administracji.

8 F. Longchamps, op. cit., s. 70.

9 Ibidem, s. 72-73.

10 Jak pisał, ,same tylko zjawiska przyrody, bez działania człowieka, nie mogłyby być zjawiskami administracyjnymi”, ibidem, s. 74.

11 F. Longchamps przywoływał poglądy przedstawicieli filozofii prawa, teorii kultury, socjologii i psychologii społecznej, które ujmowały kulturę jako system wartości wyznawanych przez człowieka wraz z procesem ich tworzenia i przekształcania, ibidem, s. 74-76.

12 Tu właśnie przejawiało się jego doświadczenie wojenne, albowiem za przykład takiego stanu faktycznego podawał skupisko wysiedlonych jeńców wojennych, gdy przestała funkcjonować administracja obozowa, a byli jeńcy nie zostali objęci żadnym innym systemem przepisów prawa, na przykład administracji wojsk wyzwoleńczych, i w ich zastępstwie wykształcały się naturalne struktury społeczne ze stanowiskami publicznymi w takim zakresie przewagi, jaka była możliwa i konieczna do przeżycia tej grupy społecznej. Zob. ibidem, s. 84. 


\section{Przyczyny zmienności administracji}

\subsection{Zmienność jako immanentna cecha zjawiska administracji publicznej}

Pisząc o pojęciu zjawiska administracyjnego, Franciszek Longchamps dochodził do wniosku, że „Administracja publiczna nie jest czymś niezmiennym” ${ }^{13}$, co było naturalną konsekwencją konstrukcji tego pojęcia, w której przede wszystkim akcentował zmianę wprowadzaną w rzeczywistości działaniem kulturowym człowieka. Skoro jednak zjawisko administracyjne wywołuje zmianę w rzeczywistości, to zmieniająca się rzeczywistość siłą rzeczy wymusza zmianę i tego zjawiska. Dlatego też w naukach administracyjnych wiele uwagi poświęcono zmienności, określając istotę, charakter i sposób przeprowadzania reform administracji publicznej. Swego czasu wyraziłem wręcz pogląd, że reformowanie administracji jest jej cechą oraz stałym procesem ${ }^{14}$, przywołując na jego poparcie poglądy wielu innych autorów ${ }^{15}$. Hubert Izdebski i Michał Kulesza podkreślali znaczenie zmian w zakresie kultury, polityki i systemów wartości w sferze gospodarki, a także w sferze techniki i technologii pracy, dowodząc, że wpływają one na otoczenie administracji, w którym wypełnia ona swoją misję publiczną, albowiem „stale musi dotrzymywać kroku zmianom zachodzącym w środowisku społecznym" i tym samym ,procesy reformowania administracji mają charakter nieustający"16.

Najszerszy jednak wykład i najbogatszy, gdy idzie o rodzaj i dobór argumentacji, o zmienności administracji pod wpływem zewnętrznych czynników na nią oddziałujących, dał Jan Boć we wrocławskim podręczniku do nauki administracji ${ }^{17}$.

13 Ibidem, s. 90.

14 Por. J. Korczak, $W$ kwestii reform konsolidacyjnych w polskim samorzadzie terytorialnym, [w:] Dziesięć lat polskich doświadczeń w Unii Europejskiej. Problemy prawnoadministracyjne, t. 2, red. J. Sługocki, Wrocław 2014, s. 47-48.

15 Chodziło zwłaszcza o wypowiedź N. Wimmera (Reform of public administration in Austria. Activities and perspectives, „Hrvatska Javna Uprawa” 2007, nr 3, s. 635), który pisał: „Reform is the constituting principle of public administration", a także Davida Špačka, który w publikacji Public administration reform wyraził pogląd o reformie jako stałym stanie administracji: „The constant reform of public administration sources also from the character of public administration itself", http://is.muni.cz/el/1456/podzim2006/PVTRPS/um/Public_Administration_Reform.pdf, s. 3 (dostęp: 14.01.2104). Podobnie pojmowała znaczenie reform dla funkcjonowania administracji R. Rys (Správni věda, nauka o správnich reformach a teorie reform, „Časopis pro právni vědu a praxi” $18,2010, \mathrm{nr}$ 2, s. 168), pisząc: „Reformy veřejné správy jsou ve své podstatě unikátním procesem zasahování do fungování veřejné správy".

16 Por. H. Izdebski, M. Kulesza, Administracja publiczna. Zagadnienia ogólne, Warszawa 1999, s. 257. Zarazem autorzy przestrzegali przed nadużywaniem hasła reformy jako uzasadnienia wydatkowania publicznych finansów czy też narzędzia walki politycznej (s. 258).

17 J. Boć, Uwarunkowania rozwoju administracji publicznej, [w:] Administracja publiczna, red. J. Boć, Wrocław 2003, rozdz. II. 
Otóż ujął je dynamicznie w historycznej kolejności ich pojawiania się i rozwoju pod względem wywieranego wpływu, sięgając do tych najstarszych, które dają się ustalić na podstawie archeologicznych badań nad pierwszymi cywilizacjami przybierającymi formy państwowe, po te zupełnie współczesne, których wpływ na zmienność administracji jest już odczuwalny, ale jeszcze nie zdiagnozowany i tym samym nieopisany. Bez wątpienia daje to możliwość prześledzenia ewolucji zjawisk administracyjnych od administracji państw starożytnych, przez administrację państw europejskich wieków średnich, do administracji państwa policyjnego i jego rewolucyjnego przeobrażenia w państwo prawne, aby zakończyć na próbach analiz przejawów zjawisk administracyjnych w dobie globalizacji. Całość tego wywodu prowadzi do oczywistych wniosków - przyczyn zmienności administracji jest wiele i odgrywały one w rozwoju cywilizacyjnym rolę zmienną, choć niektóre z nich wpływ ten wywierają nieprzerwanie. Niemniej jednak potwierdza on w pełni tytułową tezę, że proces ewolucji administracji polega między innymi na dyspersji zjawisk administracyjnych przez rozrost funkcji, celów i zadań, rozbudowę struktur organizacyjnych i wreszcie nieustanny rozrost kadr administracyjnych.

\subsection{Demograficzne czynniki zmienności zjawiska administracyjnego}

Należy zwrócić uwagę, że już sama demografia była istotnym powodem rozrostu administracji w pierwszych państwach ery starożytnej. Gdy bowiem z miast-państw, w których limitowanie terytorialne i naturalne (murami obronnymi lub umiejscowieniem) wpływało równie ograniczająco na liczbę mieszkańców będących li tylko poddanymi czy aż obywatelami, co pozwalało ówczesnym tyranom czy demokratycznie ustanowionym organom bez większego trudu sprawować nad nimi władzę, zaczęły się tworzyć państwa terytorialne (Sumerowie, Babilonia, Asyria, Egipt), a wreszcie imperia (na przykład rzymskie), gdzie na wielkich terytoriach zamieszkiwały równie duże grupy ludności, władcy potrzebowali informacji o ich liczbie, wieku, płci i rozmieszczeniu, co było niezbędne do tworzenia wojska w celach obronnych i ekspansjonistycznych, ale też do celów poboru nakładanych danin. W związku z tym przeprowadzano nie tylko okresowe spisy mieszkańców państwa, lecz z czasem zaczęto prowadzić regularną rejestrację urodzin i stałą ewidencję ludności zamieszkującej poszczególne jednostki administracyjne państwa.

Tak zatem potrzeby militarne i fiskalne stały się powodem ustalenia nowej funkcji administracji i wyodrębnienia jej specjalnych organów wraz z obsługującymi je urzędami będącymi pierwowzorem dzisiejszych urzędów statystycznych, administracji wojskowej, urzędów skarbowych itp. ${ }^{18}$ Jeśli zaś przypomnieć, że w antycznych miastach-państwach helleńskich z Atenami na czele udział w sprawowaniu władzy mogli mieć tylko obywatele danego miasta, a byli nimi wy-

18 Ibidem, s. 82-84. 
łącznie mężczyźni, którzy owo obywatelstwo mogli dowieść, to i w nich odpowiednie urzędy administracyjne musiały rejestrować obywateli uprawnionych do uczestniczenia w zgromadzeniach. Gdy zaczęła się zaś wykształcać demokracja przedstawicielska, to również do wyłaniania przedstawicieli zasiadających w stosownych organach władzy musiały istnieć odpowiednie urzędy administracyjne, które podobnie jak dzisiejsze organy administracji wyborczej rejestrowały zarówno wyborców, jak i kandydatów, a później elektów. Dalszy wzrost populacji jedynie zwiększał liczbę systemów ewidencyjnych i prowadzących je organów $\mathrm{z}$ coraz większą liczbą zatrudnionych w odpowiednich urzędach osób ${ }^{19}$.

\subsection{Handel jako cywilizacyjny czynnik zmian w administracji}

Drugim czynnikiem cywilizacyjnym dostrzeżonym przez Jana Bocia jest handel, który z pierwotnych, prymitywnych i ograniczonych przestrzennie form wymiany barterowej przerodził się w rozbudowaną sieć kupieckich gildii i faktorii. Znaczenie handlu dla rozwoju cywilizacji ludzkiej jest powszechnie znane i niekwestionowane, jednak dla analizowanego tu rozrostu administracji o nowe jej funkcje i struktury organizacyjne odgrywa szczególne znaczenie. Przede wszystkim handel doprowadzał do kontaktów państw odmiennych od siebie pod każdym względem, w tym $\mathrm{w}$ zakresie stosowanych w nich jednostek pomiaru towaru stanowiącego przedmiot wymiany handlowej oraz jednostek pieniężnych lub innych wartości wykorzystywanych jako forma zapłaty. Ustanawiane różne jednostki miary długości, objętości, powierzchni, wagi i innych systemów metrycznych stosowanych $\mathrm{w}$ handlu, łącznie $\mathrm{z}$ ilością jednostek pomiaru i liczbą sztuk, musiały być odpowiednio przeliczane w celu zapewnienia ich porównywalności. Stąd już tylko krok do współczesnych urzędów miar i urzędów probierczych w wymiarze krajowym ${ }^{20}$ oraz międzynarodowym ${ }^{21}$. Oprócz problemu miar

19 Współcześnie poza tradycyjną statystyką administracja zajmuje się ewidencjonowaniem nie tylko urodzin i zgonów oraz zmian stanu cywilnego mieszkańców państw, ale też na przykład ewidencją dzieci podlegających obowiązkowi szkolnemu, osób podlegających ubezpieczeniu zdrowotnemu i społecznemu, ewidencją beneficjentów wszelkich form i postaci świadczeń w ramach zabezpieczenia społecznego (na przykład pomocy społecznej), rejestrami osób wykonujących zawody reglamentowane (na przykład lekarzy) czy uprawnionych do prowadzenia pojazdów i innych. Zob. na ten temat szerzej J. Korczak, $O$ zwiazkach administracji publicznej ze statystyka publiczna na przyktadzie samorzadu terytorialnego, [w:] Statystyka publiczna w stużbie samorzadu terytorialnego. Konferencja naukowa Wrocław 7-8 marca 2011 r., red. S. Kamiński, E. Mazurek („Biblioteka Wiadomości Statystycznych”, t. 65), Warszawa 2011, s. 35-52; T. Stawecki, Rejestry publiczne. Funkcje instytucji, Warszawa 2005.

${ }^{20}$ Działają na podstawie przepisów ustawy z dnia 11 maja 2001 roku - Prawo o miarach (Dz.U. z 2019 r. poz. 541) kontynuującego stuletnią historię polskiej administracji miar zapoczątkowaną dekretem o miarach z dnia 8 lutego 1919 roku (Dz.Pr.P. Nr 15, poz. 211).

21 Trzeba mieć na względzie konwencję dotyczącą utworzenia i utrzymania Międzynarodowego Biura Miar, wraz z regulaminem, przyjętą w Paryżu dnia 20 maja 1875 roku (Dz.U. z 1925 r. 
i systemów jednostek równie istotne stało się czerpanie z handlu korzyści przez panujących, którzy kontrolowali prowadzenie handlu na terenie swojego kraju przez kupców z innych państw, stosując ochronę własnego handlu za pomocą odpowiedniego systemu ceł, a także poboru różnych opłat (na przykład myta) i innych rozwiązań prawnych (na przykład przymusu drogowego czy targowego), co powodowało powstanie pierwszych komór celnych ${ }^{22}$.

Handel z czasem zaczął być też przedmiotem organizacji wewnątrz państw ${ }^{23}$ oraz $\mathrm{w}$ płaszczyźnie międzynarodowej, prowadząc do powstania odrębnych urzędów zajmujących się handlem międzynarodowym ${ }^{24}$. Współczesne rozmiary handlu w każdym jego wymiarze przestrzennym generują coraz więcej regulacji prawnych, do których stosowania tworzy się także coraz więcej instytucji o charakterze kontrolnym, typowych dla sfery administracji publicznej. Są to organizacje międzynarodowe zajmujące się zarówno bezpieczeństwem produktów będących przedmiotem handlu ${ }^{25}$, jak i ich jakością ${ }^{26}$, a także ochroną praw konsumentów ${ }^{27}$.

Nr 87, poz. 608) oraz konwencję ustanawiającą Międzynarodową Organizację Metrologii Prawnej przyjętą w Paryżu dnia 12 października 1955 roku (Dz.U. z 1959 r. Nr 4, poz. 24).

${ }_{22}$ Zob. W. Czyżowicz, M. Woźniczko, Cto i celnicy w historii. Struktury i mechanizmy działania, Warszawa 2012; A. Kuś, Cło i postępowanie celne w Polsce przedrozbiorowej, „Rocznik Nauk Prawnych" 2, 2002, z. 1.

${ }^{23} \mathrm{~W}$ celu zapewnienia właściwego funkcjonowania instytucji zajmujących się handlem utworzono Państwową Inspekcję Handlową dekretem z dnia 21 września 1950 roku (Dz.U. Nr 44, poz. 396), zastąpionym dnia 25 lutego 1958 roku ustawą o Inspekcji Handlowej (Dz.U. z 1999 r. Nr 105, poz. 1205) i obecnie obowiązującą ustawą z dnia 15 grudnia 2000 roku (Dz.U. z 2019 r. poz. 1668).

24 Jedynie dla przykładu można przywołać porozumienie ustanawiające Światową Organizację Handlu (WTO), sporządzone w Marakeszu dnia 15 kwietnia 1994 roku (Dz.U. z 1995 r. Nr 98, poz. 483), w przypadku organizacji krajowych zaś wskazać należy działającą w latach 1949-1989 Polską Izbę Handlu Zagranicznego utworzoną dekretem z dnia 28 września 1949 roku (Dz.U. Nr 53, poz. 403), obecnie będącą wyodrębnioną częścią Krajowej Izby Gospodarczej na mocy art. 12 ustawy z dnia 30 maja 1989 roku o izbach gospodarczych (Dz.U. z 2019 r. poz. 579). W okresie funkcjonowania państwa socjalistycznego działalność polskich przedsiębiorców na rynku handlu międzynarodowego była ściśle reglamentowana, co wyposażało organ administracji centralnej w wiele narzędzi, jak choćby w zarządzeniu nr 10 Ministra Finansów z dnia 6 lutego 1985 roku w sprawie czynności z zakresu handlu zagranicznego i usług związanych z tym handlem, na które indywidualnych zezwoleń dewizowych udziela Minister Handlu Zagranicznego (Dz.Urz. MF Nr 3, poz. 4). Do 2000 roku na podstawie ustawy z dnia 12 września 1996 roku o państwowym nadzorze standaryzacyjnym towarów rolno-spożywczych w obrocie z zagranicą (Dz.U. Nr 124, poz. 584) działał Centralny Inspektorat Standaryzacji.

${ }^{25}$ W wymiarze unijnym służy temu celowi Komitet ds. Stosowania Porozumienia w Sprawie Barier Technicznych w Handlu utworzony na mocy art. 8 decyzji Rady z dnia 15 stycznia 1980 roku ustanawiającej przepisy w sprawie wprowadzenia i stosowania regulacji norm technicznych (Dz. Urz. UE. L Nr 14, poz. 36).

26 Jako przykład może posłużyć Inspekcja Jakości Artykułów Rolno-Spożywczych utworzona na mocy ustawy z dnia 21 grudnia 2000 roku o jakości handlowej artykułów rolno-spożywczych (Dz.U. z 2019 r. poz. 2178), która zastąpiła działającą od 1970 roku Inspekcję Skupu i Przetwórstwa Artykułów Rolnych (Dz.U. z 2000 r. Nr 23, poz. 293), będącą następczynią powołanej ustawą z dnia 9 czerwca 1952 roku Inspekcji Zbożowej (Dz.U. Nr 30, poz. 202).

27 Na mocy przepisów ustawy z dnia 16 lutego 2007 roku o ochronie konkurencji i konsumentów (Dz.U. z 2019 r. poz. 369) został powołany Urząd Ochrony Konkurencji i Konsumentów, 


\subsection{Wynalazki techniczne i ich wpływ na ewolucję zadań i organizacji administracji}

Bez wątpienia miarą rozwoju cywilizacyjnego jest technika, która na przełomie XVIII i XIX wieku stała się swoistym katalizatorem jego znacznego przyspieszenia, początkując epokę rewolucji przemysłowej z wszystkimi jej, także ekonomicznymi, społecznymi i politycznymi, następstwami. Wynalazek maszyny parowej, dokonany co prawda jeszcze na początku XVIII wieku przez Thomasa Newcomena, a udoskonalony przez Jamesa Watta w drugiej połowie wieku, dopiero na początku XIX stulecia wszedł na stałe do wyposażenia ówczesnych fabryk, głównie przemysłu metalowego i kopalń, a już w latach 1802 i 1804 zaczął poruszać pojazdy szynowe i kołowe, a także wodne, i wówczas wynalazek odsłonił swoje drugie oblicze. Nieznane siły fizyczne występujące w tych konstrukcjach przy ich niedoskonałości (praktycznie sprawdzano każdy element konstrukcji kotła parowego i sposobu wykorzystywania jego energii do poruszania podłączanych maszyn i urządzeń), a także bardzo niskiej wiedzy technicznej obsługujących je pracowników stawały się przyczyną awarii i poważniejszych katastrof przemysłowych pochłaniających też ofiary ludzkie. Dlatego pierwsze przepisy określające warunki techniczne dotyczące maszyn i kotłów parowych oraz zasad i trybu wydawania zezwoleń na ich instalowanie, a także zakresu badań sprawdzających ich stan techniczny i wytrzymałość powstały w 1813 roku w Austrii ${ }^{28}$, a w 1828 roku w Prusach ${ }^{29}$. Ustanawiały one również nadzór nad wytwórcami oraz przedsiębiorcami stosującymi te urządzenia, powoływano do tego osobne urzędy lub też zezwalano na wykonywanie nadzoru w imieniu państwa przez tworzone w tym celu stowarzyszenia techniczne. W konsekwencji w drugiej połowie XIX wieku powołano najpierw w Manchesterze Stowarzyszenie Dozoru Kotłów Parowych, a w 1888 roku Międzynarodowy Związek Stowarzyszeń Dozorów Kotłów.

W Polsce pierwsza regulacja w tym zakresie powstała w 1921 roku $^{30}$ i odegrała istotną rolę w ujednoliceniu przepisów obowiązujących dotychczas na ziemiach polskich z okresu rozbiorowego, znosząc w art. 8 obowiązywanie prawa państw zaborczych i ustanawiając nadzór centralnych organów administracji rządowej. Zakres regulacji rozszerzono następnie w 1933 roku o nadzór nad wszel-

którego prezes jest wyposażony w wiele uprawnień decyzyjnych (dział V, rozdz. 1), a w powiatach i miastach na prawach powiatów starostowie i prezydenci miast zatrudniają powiatowych i miejskich rzeczników praw konsumentów (dział V, rozdz. 2).

28 Zob. C. Gochnat. Repertorium sämtlicher vom Jahre 1800 bis einschließlich 1845 für die Provinz Nieder-Österreich erlassenen politischen und Justiz Gesetze und Verordnungen. In alphabetisch-chronologischer Ordnung, t. 1, Wien 1846, s. 488-494.

29 Zob. B. Helliinger, Die geschichtliche Entwicklung der Dampfkesselaufsicht in Preußen, [w:] Beiträge zur Geschichte der Technik und Industrie, red. C. Matchoss, „Jahrbuch der Vereines Deutscher Ingenieure" 7, 1916, s. 63-64.

${ }^{30}$ Ustawa z dnia 31 maja 1921 roku o nadzorze nad kotłami parowymi (Dz.U. Nr 50, poz. 303). 
kimi zbiornikami pod ciśnieniem ${ }^{31}$, a obie regulacje dały podstawy do utworzenia w 1950 roku Urzędu Dozoru Technicznego ${ }^{32}$. Następujące w późniejszym czasie regulacje utrzymały Urząd, rozbudowując i zmieniając jego strukturę terenową, w miarę jak rozszerzał się zakres zadań w tej dziedzinie pod wpływem coraz to nowszych technologicznie urządzeńn ${ }^{33}$.

Wykorzystanie kotłów parowych do napędzania pierwszych pojazdów szynowych i kołowych stworzyło także nowe problemy w zakresie jeszcze wówczas mało uregulowanych zasad ruchu drogowego ${ }^{34}$, toteż dopiero w 1835 roku w Wielkiej Brytanii ustalono po raz pierwszy jako ustawowo obowiązującą zasadę lewostronne poruszanie się pojazdów parowych na drogach ${ }^{35}$, a dopiero w 1896 roku po raz pierwszy ograniczono prędkość ich poruszania się w ruchu publicznym (przepis ten objął także pojazdy spalinowe) ${ }^{36}$. Jednak dopiero regulacje z początku XX wieku postawiły przed administracją publiczną nowe zadania, albowiem kolejna ustawa brytyjska, z 1903 roku $^{37}$, wprowadziła po raz pierwszy

31 Ustawa z dnia 14 marca 1933 roku o nadzorze nad zbiornikami pod ciśnieniem (Dz.U. $\mathrm{Nr} 28$, poz. 234).

32 Dekret z dnia 26 października 1950 roku o Urzędzie Dozoru Technicznego (Dz.U. Nr 49, poz. 440). Wiązało się to ostatecznie z zakończeniem działalności Stowarzyszenia Dozoru Kotłów utrzymanego pod rządami ustawy z 1921 roku (art. 11).

33 Dekret został zastąpiony najpierw ustawą z dnia 31 stycznia 1961 roku o dozorze technicznym (Dz.U. Nr 5, poz. 31), która rozszerzała dotychczasowe zadania o wytwornice acetylenowe oraz dźwignice (art. 1), a następnie ustawą z dnia 19 listopada 1987 roku o dozorze technicznym (Dz.U. $\mathrm{Nr} 36$, poz. 202), która wprowadzała ustrój dozoru rozbudowany o inspektoraty i inne specjalistyczne organy dozoru technicznego (rozdz. 3), a ostatecznie obowiązującą ustawą z dnia 21 grudnia 2000 roku o dozorze technicznym (Dz.U. z 2019 r. poz. 667), która rozciągnęła dozór na wszelkie urządzenia techniczne (art. 5), rozbudowała znacznie katalog form działania (rozdz. 2) i nadała mu nową strukturę z trzema centralnymi organami: Urzędem Dozoru Technicznego, Transportowym Dozorem Technicznym oraz Wojskowym Dozorem Technicznym, wraz z ich oddziałami terenowymi (rozdz. 3).

34 Nie chodzi wyłącznie o prawo i lewostronny ruch na drogach, choć papież Bonifacy VIII już w 1300 roku ustalił, że pielgrzymi w drodze do miejsc kultu mają iść lewą stroną (od serca); z innych powód jeden z cesarzy japońskich nakazał ruch lewostronny w celu uniknięcia zatargów uzbrojonych samurajów, a Highway Act z 1773 roku w Wielkiej Brytanii nakazywał lewostronny ruch koni i zaprzęgów konnych. W Polsce (podobnie jak w większości państw kontynentalnej Europy) obowiązywał zawsze ruch prawostronny, począwszy od regulacji państw zaborczych, przez art. 6 ustawy z dnia 7 października 1921 roku o przepisach porządkowych na drogach publicznych (Dz.U. Nr 89, poz. 656), aż po regulacje współczesne.

35 An Act to consolidate and amend the Laws relating to Highways in that Part of Great Britain called England 31 August 1835, CAP. L, s. 369-428, Office of Public Sector Information, London 1835.

${ }^{36}$ An Act for regulating the Use of Locomotives on Turnpike and other Roads 14 November 1896, CAP LXX, Pratt's Law of Highways Edition 10.

37 Motor Car Act 14 August 1903, „The London Gazette”, nr 27589. W istocie była to nowelizacja ustawy z 1896 roku, podwyższająca w art. 9 ustalony wówczas limit prędkości do $20 \mathrm{mil} / \mathrm{h}$. Zgodnie $\mathrm{z}$ art. 2 każdy pojazd silnikowy musiał być zarejestrowany w urzędzie hrabstwa po wniesieniu opłaty (20 szylingów za samochód i 5 szylingów za motocykl) pod rygorem rekwizycji do uzyskania rejestracji oraz kary 3 funtów dla kierującego takim pojazdem. Z kolei art. 3 ustalał zakaz prowadzenia na drogach publicznych pojazdów silnikowych bez uzyskania pozwolenia w urzędzie 
obowiązek rejestracji pojazdów (art. 2) oraz uzyskania uprawnienia do prowadzenia pojazdów mechanicznych po drogach publicznych (art. 3).

Zaledwie sześć lat później tego typu regulacje stały się przedmiotem prawa międzynarodowego i konwencja paryska ${ }^{38}$, przyjęta przez 16 państw europejskich (Polska przystąpiła do niej dopiero po odzyskaniu niepodległości, w 1923 roku), ustalała już jednolite dla kontynentu europejskiego zasady budowy pojazdów (art. 1 i art. 6 pkt 1), zasady udzielania pozwoleń na prowadzenie pojazdów (w art. 2 podniesiono angielską granicę do 18. roku życia), zasady poruszania się pojazdów zarejestrowanych w danym kraju na terenie innych państw (art. 3) oraz rejestracji samych pojazdów z oznaczeniem ich przynależności państwowej (art. 4 i 6 pkt 3) i umieszczania urządzeń sygnalizacyjnych niezbędnych do bezpieczeństwa na drodze (art. 5 i art. 6 pkt 2 i 4). Co więcej, zaczęto w konwencji ujednolicać przepisy ruchu drogowego i znaki drogowe (art. 7-9).

Kiedy zatem niepodległe państwo polskie wreszcie mogło rozpocząć własne regulowanie zasad poruszania się po drogach publicznych, co nastąpiło we wspomnianej ustawie z 1921 roku oraz wydawanych na jej podstawie rozporządzeniach wykonawczych, wśród których szczególną rolę odegrało rozporządzenie z 1922 roku $^{39}$, oczywiście wzorowano się na zasadach wynikających z konwencji paryskiej. Rozporządzenie szczegółowo określało wymagania dotyczące budowy i urządzenia pojazdów mechanicznych (§ 4-6), których spełnienie warunkowało dopuszczenie ich do ruchu ( $(7-15)$, ponadto zasady ich rejestracji z używaniem oznaczeń ustalonych dla poszczególnych województw (§ 16-23). Polskie rozporządzenie, w odróżnieniu od liberalnych przepisów brytyjskich, ustalało bardzo rygorystyczne zasady udzielania zezwoleń na prowadzenie danego typu pojazdu dla osób, które nie tylko ukończyły 18 lat i mają odpowiedni stan zdrowia, ale przede wszystkim odbyły naukę i trzymiesięczną praktykę prowadzenia pojazdów ( 24 ), a na koniec zdały egzamin przed właściwą komisją egzaminacyjną (§ 26), przy czym pozwolenie mogło być cofnięte na stałe lub okresowo przez właściwego miejscowo wojewodę w związku z zaistnieniem wskazanych w rozporządzeniu przesłanek (§ 27). Już tylko te przepisy rozporządzenia (oczywiście regulowano w nim przepisy bezpieczeństwa ruchu dotyczące prędkości i inne) dowodzą, jak

właściwym ze względu na miejsce zamieszkania po wniesieniu opłaty 5 szylingów, przy czym licencja kierowcy była ważna jedyne 12 miesięcy od daty wydania. Warunkiem uzyskania pozwolenia było ukończenie 17 lat do prowadzenia samochodów i 14 lat do kierowania motocyklem, pozwolenie zaś zgodnie z art. 4 mogło być odebrane, a kierowca pozbawiony uprawnień na czas określony przez sąd w razie stwierdzenia przekroczenia limitu prędkości bądź prowadzenia pojazdu bez wymaganego uprawnienia. Ustawa z art. 10 przewidywała także możliwość orzeczenia kary pozbawienia wolności do 3 miesięcy poza karami grzywny.

38 Konwencja międzynarodowa dotycząca ruchu samochodowego zawarta 11 października 1909 roku w Paryżu, zatwierdzona ustawą z 28 września 1922 roku (Dz.U. z 1923 r. Nr 86, poz. 668).

39 Rozporządzenie Ministra Robót Publicznych i Ministra Spraw Wewnętrznych z dnia 6 lipca 1922 roku o ruchu samochodów i innych pojazdów mechanicznych na drogach publicznych (Dz.U. $\mathrm{Nr} 65$, poz. 587). 
szeroki był zakres nowych zadań nakładanych głównie na wojewodów (okręgowe dyrekcje robót publicznych i okręgowe komendy policji państwowej brały udział w czynnościach technicznych i kontrolnych), którzy wydawali i cofali zaświadczenia dopuszczające pojazdy do ruchu (§9), rejestrowali pojazdy (§16) i wydawali oraz cofali pozwolenia na prowadzenie pojazdów ( $\$ 24$ i 27), powołując w tym celu komisje egzaminacyjne ( $(26)$. Następne regulacje prawne w tym zakresie $^{40}$ jeszcze bardziej rozbudowywały te zadania w miarę rozwoju motoryzacji zarówno w zakresie konstrukcji technicznych, jak i coraz większej liczby użytkowników pojazdów ${ }^{41}$, dokonując też dekoncentracji organów administracji właściwych w poszczególnych zakresach postępowań ${ }^{42}$. Zmiany w prawie o ruchu drogowym po II wojnie nastąpily dopiero po 1961 roku, kiedy wydano nową ustawę ${ }^{43}$, uchylając przepisy ustawy z 1921 roku oraz jej rozporządzeń wykonawczych, które zastąpiły między innymi przywoływane już rozporządzenie z 1962 roku, a następnie rozporządzenie z 1968 roku $^{44}$. Już tylko porównanie liczby jednostek redakcyjnych w tych nowych aktach prawa (237 paragrafów wobec 47 paragrafów rozporządzenia z 1922 roku) ilustruje dynamiczny wzrost zadań administracji, ale od 1997 roku, kiedy weszło w życie obecne prawo o ruchu drogowym, wzrost jest wręcz lawinowy, w dodatku towarzyszy mu tworzenie zupełnie nowych organów administracji publicznej wykonujących zadania specjalistyczne ${ }^{45}$.

40 Rozporządzenie Ministra Robót Publicznych i Ministra Spraw Wewnętrznych w porozumieniu z Ministrem Spraw Wojskowych z dnia 27 stycznia 1928 roku (Dz.U. Nr 41, poz. 396) wprowadziło pierwszą ewidencję pojazdów i kierowców (§ 113-118), będącą swoistym pierwowzorem współczesnej centralnej ewidencji pojazdów w systemie teleinformatycznym wprowadzonej w 2000 roku do ustawy z dnia 20 czerwca 1997 roku — Prawo o ruchu drogowym (Dz.U. z 2020 r. poz. 110), dział III, rozdz. 2a. Ta sama nowela wprowadziła także obowiązującą obecnie centralną ewidencję kierowców w dziale IV, rozdz. 1a.

41 W kolejnym rozporządzeniu, z dnia 15 stycznia 1933 roku (Dz.U. Nr 9, poz. 55), po raz pierwszy wprowadzono oznaczenie pojazdu „nauka jazdy” wykorzystywanego w trakcie nauki jazdy osób ubiegających się o uzyskanie pozwolenia na prowadzenie pojazdów (§ 21), ale dopiero rozporządzenie Ministrów Komunikacji i Spraw Wewnętrznych z dnia 1 października 1962 roku w sprawie ruchu drogowego na drogach publicznych (Dz.U. Nr 61, poz. 295) uregulowało zasady tworzenia i prowadzenia ośrodków szkolenia kierowców, do czego wymagane było zezwolenie prezydium wojewódzkiej rady narodowej (rozdz. 2), co było kolejnym zadaniem administracji z zakresu ruchu drogowego.

42 Rozporządzenie z dnia 27 października 1937 roku (Dz.U. Nr 85, poz. 616), wydane dodatkowo jeszcze w porozumieniu z Ministrem Opieki Społecznej, przenosiło sprawy ewidencji pojazdów na organy powiatu ( $(2)$, podobnie jak wydawanie pozwoleń kierowcom zawodowym ( $(45)$, ale też, co ciekawe, upoważniając po raz pierwszy organizacje społeczne reprezentujące interesy automobilizmu do wydawania pozwoleń kierowcom niezawodowym $(\S 43)$.

43 Ustawa z dnia 27 listopada 1961 roku o bezpieczeństwie i porządku ruchu na drogach publicznych (Dz.U. Nr 53, poz. 295). Zastąpiona została ustawą z dnia 1 lutego 1983 roku — Prawo o ruchu drogowym (Dz.U. z 1992 r. Nr 11, poz. 41).

44 Rozporządzenie z dnia 20 lipca 1968 roku w sprawie ruchu na drogach publicznych (Dz.U. $\mathrm{Nr}$ 27, poz. 183).

${ }^{45}$ Są to dla przykładu wojewódzkie ośrodki ruchu zajmujące się między innymi organizowaniem egzaminów państwowych sprawdzających kwalifikacje do kierowania pojazdami (dział IV, 
Należy też zauważyć, że oprócz rozwoju motoryzacji i ruchu pojazdów kołowych po drogach publicznych od połowy XIX wieku rozwijał się transport szynowy, który w podobny sposób wpłynął na zwiększenie liczby zadań administracji zajmującej się jego organizacją i zapewnieniem bezpieczeństwa ${ }^{46}$. W XX wieku rozpoczął także swoją historię transport lotniczy, który również wymusił stworzenie odpowiednich organów administracji publicznej wykonujących niezbędne zadania związane z organizacją i bezpieczeństwem jego wykonywania ${ }^{47}$. Także transport wodny — zarówno morski, jak i śródlądowy — w wyniku regulacji prawnych wprowadzanych w ciągu lat wykształcił osobną administrację morską ${ }^{48}$ i śródlądową ${ }^{49}$, zapewniające odpowiednią organizację i utrzymanie niezbędnej infrastruktury, jak również bezpieczeństwo samego transportu.

Praktycznie jednak każdy wynalazek techniki prowadził do wykształcenia nowych zadań administracji, a przy tym często też do stworzenia nowych jej organów i jednostek organizacyjnych. Wynalazek telefonu Alexandra Grahama Bella z 1876 roku pozwalał w szybkim czasie na zbudowanie sieci połączeń telefonicznych niemal na całym świecie i w wielu państwach świadczenie usług telefonicznych było przedmiotem działalności gospodarczej, jednak w równie wielu działalność ta została objęta monopolem państwowym. Tak było też w wypadku Polski od momentu odzyskania niepodległości aż do 1990 roku $^{50}$, co wiązało się

rozdz. 3) czy Inspekcja Transportu Drogowego zajmująca się kontrolowaniem przestrzegania przepisów w zakresie przewozu drogowego i publicznego transportu zbiorowego utworzona na mocy przepisów rozdziału 9 ustawy z dnia 6 września 2001 roku (Dz.U. z 2019 r. poz. 2140).

46 Ustawa z dnia 28 marca 2003 roku o transporcie kolejowym (Dz.U. z 2019 r. poz. 710) przewiduje wiele zadań związanych z organizacją i utrzymaniem transportu kolejowego centralnego organu administracji rządowej Prezesa Urzędu Transportu Kolejowego (rozdz. 3).

47 Ustawa z dnia 3 lipca 2002 roku - Prawo lotnicze (Dz.U. z 2019 r. poz. 1580) przewiduje wiele zadań centralnego organu administracji rządowej Prezesa Urzędu Lotnictwa Cywilnego (rozdz. 2), a oprócz tego ustawa z dnia 8 grudnia 2006 roku o Polskiej Agencji Żeglugi Powietrznej (Dz.U. z 2017 r. poz. 1967) przewidziała utworzenie państwowej osoby prawnej zapewniającej w przestrzeni powietrznej służbę ruchu lotniczego, a także służbę łączności, nawigacji, dozorowania oraz informacji lotniczej.

48 Są to przede wszystkim dyrektorzy urzędów morskich z inspekcjami morską, bandery i portu, Służbą Kontroli Ruchu Statków, kapitanatami i bosmanatami portów oraz Biurem Spraw Obronnych Żeglugi, przewidziani art. 39 ustawy z dnia 21 marca 1991 roku o obszarach morskich Rzeczypospolitej Polskiej i administracji morskiej (Dz.U. z 2019 r. poz. 2169).

49 Ustawa z dnia 21 grudnia 2000 roku o żegludze śródlądowej (Dz.U. z 2019 r. poz. 1568) w art. 8 ustanawia urzędy żeglugi śródlądowej w Bydgoszczy (z delegaturami w Gdańsku, Giżycku i Warszawie), Wrocławiu (z delegaturami w Kędzierzynie-Koźlu i Krakowie) i Szczecinie z ich dyrektorami (i odpowiednio dyrektorami delegatur) z zadaniami w zakresie nadzoru nad bezpieczeństwem żeglugi oraz kontrolą statków i szlaków wodnych (art. 9), wykonywanymi przez inspektorów zatrudnionych w poszczególnych urzędach i delegaturach.

50 Już dekret $\mathrm{z}$ dnia 7 lutego 1919 roku o tymczasowych przepisach pocztowych (Dz.P.P.P. $\mathrm{Nr}$ 17, poz. 222) w art. 1 ustanawiał monopol państwa na instytucje i urządzenia: „Nikt poza Ministerstwem Poczty i Telegrafów nie ma prawa zaprowadzać urządzeń pocztowych, telegraficznych i telefonicznych" z wyjątkiem budowy urządzeń telefonicznych przez właścicieli gruntów w obrębie granic jednego gruntu lub będącymi w zarządzie jednego właściciela gruntami, pod warunkiem 
z reglamentowaniem samych usług (abonent otrzymywał decyzją administracyjną zezwolenie na przyłączenie do sieci oraz nadany mu numer telefoniczny ${ }^{51}$ ). Dopiero w trakcie transformacji ustrojowej przełomu lat 1989-1990 odstąpiono od takiego modelu regulacji na rzecz uwolnienia rynku usług telekomunikacyjnych ${ }^{52}$, które najpierw poddano kontroli Ministerstwa Łączności, a od 1995 roku utworzonej w tym celu Państwowej Inspekcji Telekomunikacyjnej i Pocztowej ${ }^{53}$, przekształconej w 2001 roku w Urząd Regulacji Telekomunikacji ${ }^{54}$, a następnie, w 2002 roku, w Urząd Regulacji Telekomunikacji i Poczty ${ }^{55}$, aby ostatecznie poddać go kontroli Urzędu Komunikacji Elektronicznej ${ }^{56}$.

że ich odległość nie przekracza $25 \mathrm{~km}$ (art. 5), co i tak wymagało zezwolenia i pozostawało pod nadzorem ministerstwa. Stan ten utrzymywała zarówno ustawa z dnia 27 maja 1919 roku o państwowej wyłączności poczty, telegrafu i telefonu (Dz.P.P.P. Nr 44, poz. 310), jak i jej następczyni, ustawa z dnia 3 czerwca 1924 roku o poczcie, telegrafie i telefonie (Dz.U. z 1933 r. Nr 63, poz. 481), zastąpiona najpierw dekretem z dnia 11 marca 1955 roku o łączności (Dz.U. Nr 12, poz. 71), a później ustawą z dnia 31 stycznia 1961 roku o łączności (Dz.U. Nr 8, poz. 48) i ustawą z dnia 15 listopada 1984 roku o łączności (Dz.U. Nr 54, poz. 275).

51 Zgodnie z § 9 i 10 rozporządzenia Ministra Łączności z dnia 23 czerwca 1986 roku w sprawie ordynacji telekomunikacyjnej (Dz.U. Nr 27, poz. 135) przyznanie abonamentu stacji telefonicznej następowało na wniosek zainteresowanej osoby złożony we właściwym terenowo urzędzie telekomunikacyjnym, którego dyrektor przyznaje abonament z uwzględnieniem opinii komisji do spraw przyznawania abonamentu, w skład której wchodzili przedstawiciele urzędu oraz terenowego organu administracji państwowej stopnia podstawowego. Przepis $\S 12$ szczegółowo regulował przejmowanie abonamentu w przypadku śmierci abonenta przez jego spadkobierców oraz innych przypadków przekazywania lub przejmowania abonamentu przez inne osoby. Abonent był zobowiązany w każdym czasie umożliwić organom kontrolnym przeprowadzanie kontroli stanu technicznego urządzeń i ich obsługi (§ 18). Już tylko te przepisy uświadamiają złożoność samej struktury (dwa organy zaangażowane w wydanie decyzji) oraz samej procedury załatwiania wniosku i dalszych postępowań związanych z korzystaniem z abonamentu.

52 Co nastąpiło dzięki ustawie z dnia 23 listopada 1990 roku o łączności (Dz.U. z 1995 r. $\mathrm{Nr}$ 117, poz. 564), która potraktowała działalność w dziedzinie telekomunikacji jako gospodarczą, ograniczoną jedynie do uzyskania świadectwa dopuszczenia do eksploatacji (art. 4 i 7), prowadzoną przez operatorów sieci (art. 10), którzy uzyskali stosowane zezwolenia (art. 12-20), podlegającą kontroli (art. 29 i 30). O zezwoleniach zob. M. Szydło, Zezwolenie telekomunikacyjne, „Kwartalnik Prawa Publicznego" 2003, nr 2, s. 113-137. Niemniej jednak tryb administracyjny przydzielania stacji telefonicznych został zastąpiony umową cywilnoprawną o świadczenie usługi telekomunikacyjnej z operatorem dowolnie wybranej sieci.

53 Na podstawie art. 1 pkt 31 ustawy z dnia 12 maja 1995 roku o zmianie ustawy o łączności oraz niektórych innych staw (Dz.U. Nr 60, poz. 310).

$54 \mathrm{Na}$ mocy art. 109 i 139 ustawy z dnia 21 lipca 2000 roku - Prawo telekomunikacyjne (Dz.U. Nr 73, poz. 852).

$55 \mathrm{Na}$ mocy art. 1 pkt 1 lit. h i art. 20 ustawy z dnia 1 marca 2002 roku o zmianach w organizacji i funkcjonowaniu centralnych organów administracji rządowej i jednostek im podporządkowanych oraz o zmianie niektórych ustaw (Dz.U. Nr 25, poz. 253).

56 Na mocy art. 13 pkt 2 ustawy z dnia 29 grudnia 2005 roku o przekształceniach i zmianach w podziale zadań i kompetencji organów państwowych właściwości w sprawach łączności, radiofonii i telewizji (Dz.U. Nr 267, poz. 2258), który dokonał zmiany w art. 6 ustawy z dnia 16 lipca 2004 roku — Prawo telekomunikacyjne (Dz.U. z 2019 r. poz. 2460). 
Podobną ewolucję obserwujemy w dziedzinie łączności radiowej zapoczątkowanej opatentowaniem w 1897 roku przez Guglielma Marconiego systemu łączności bezprzewodowej, jednak dopiero w latach dwudziestych XX wieku zaczęły powstawać stacje radiowe, w tym - w 1926 roku — stacja „Warszawa” Polskiego Towarzystwa Radiofonicznego, która została poddana rygorom ustawy z 1924 roku i wszystkim późniejszym dotyczącym telekomunikacji z racji wspólnego traktowania obu form komunikacji. Również późniejszy wynalazek, Johna Logie'a Bairda, przesyłania obrazu za pomocą fal elektromagnetycznych i tym samym emitowania transmisji telewizyjnych z 1926 roku w Polsce, pomijając eksperymenty sprzed II wojny światowej, doprowadził do rozpoczęcia działalności Telewizji Polskiej jako instytucji państwowej. Po II wojnie jednak nowy ustrój państwa wpłynął między innymi na utworzenie najpierw przedsiębiorstwa państwowego „Polskie Radio”, podlegającego bezpośrednio PKWN ${ }^{57}$, a później także Centralnego Urzędu Radiofonii ${ }^{58}$, które zostały następnie przekształcone w Komitet do Spraw Radiofonii „Polskie Radio” 59 , a później Komitet do Spraw Radia i Telewizji „Polskie Radio i Telewizja"60. Dopiero po transformacji ustrojowej, która pozwoliła także na uwolnienie rynku nadawców radiowych i telewizyjnych, pojawiły się pierwsze rozgłośnie radiowe i telewizyjne, poddane jednak rygorom regulacyjnym podobnym jak w wypadku telekomunikacji dzięki obowiązującej nadal ustawie z 1992 roku, która przewidziała nowy organ w postaci Krajowej Rady Radiofonii i Telewizji jako naczelny organ administracji państwowej, po raz pierwszy niepodlegający administracji rządowej ${ }^{61}$. Mimo to obowiązek rejestracji odbiorników radiowych i telewizyjnych oraz ponoszenia z tytułu ich użytkowania opłaty abonamentowej, wprowadzony jeszcze ustawą z 1924 roku, nadal jest utrzymywany z możliwością kontroli osób zajmujących lokale

57 Dekret PKWN z dnia 22 listopada 1944 roku o utworzeniu Przedsiębiorstwa Państwowego „Polskie Radio” (Dz.U. Nr 13, poz. 69).

58 Ustawa z dnia 4 lutego 1949 roku o utworzeniu i zakresie działania Centralnego Urzędu Radiofonii (Dz.U. Nr 5, poz. 50). Jego strukturę określało zarządzenie Prezesa Rady Ministrów z dnia 29 października 1949 roku w sprawie tymczasowej organizacji Centralnego Urzędu Radiofonii (M.P. Nr A-80, poz. 987), mimo nazwy i raczej skromnych możliwości, skoro do pierwszej emisji doszło w 1952 roku, zajmującego się nie tylko przekazem radiowym, ale też telewizyjnym.

59 Dekret z dnia 2 sierpnia 1951 roku o utworzeniu i zakresie działania Komitetu do Spraw Radiofonii „Polskie Radio” (Dz.U. Nr 41, poz. 308) jako organu rządu (art. 2).

${ }^{60}$ Ustawa z dnia 2 grudnia 1960 roku o Komitecie do Spraw Radia i Telewizji „Polskie Radio i Telewizja” (Dz.U. Nr 54, poz. 307) jako centralnym organie administracji państwowej działającym przy Radzie Ministrów (art. 1 ust. 2).

61 Ustawa z dnia 29 grudnia 1992 roku o radiofonii i telewizji (Dz.U. z 2019 r. poz. 361). Zważyć należy, że zgodnie z art. 7 skład Krajowej Rady pochodzi z powołania dwóch członków przez Sejm, dwóch przez Senat i jednego przez Prezydenta i tym samym tym trzem organom Rada składa coroczne sprawozdania ze swojej działalności (art. 12). Do zapewnienia realizacji zadań ustawa utworzyła jako organ pomocniczy Biuro Krajowej Rady z pracownikami zatrudnianymi na podstawie przepisów pragmatyki urzędniczej z 1982 roku (art. 11). 
mieszkalne w celu ustalenia użytkowania w nich odbiorników zarejestrowanych oraz egzekucji należności abonamentowej ${ }^{62}$.

Nie tylko wynalazki techniczne, lecz także odkrycia praw i zjawisk natury generują zadania administracji, a w konsekwencji również jej nowe organy. Przykładem może być odkrycie w 1898 roku przez Marię Curie-Skłodowską i Piotra Curie pierwszych pierwiastków promieniotwórczych. Wykorzystująca wyniki badań chemicznych wiedza fizyczna doprowadziła bowiem do wykorzystania tych pierwiastków w różnych dziedzinach ludzkiej działalności, w tym medycynie, a z czasem też wojskowości, a tym samym spowodowała objęcie ich kontrolą państwową. Stąd tylko krok do stworzenia specjalistycznych organów, co w Polsce nastąpiło stosunkowo późno, bo dopiero w 1982 roku. Powstała wówczas Państwowa Agencja Atomistyki uzyskała status centralnego organu administracji państwowej ${ }^{63}$ (obecnie Prezes PAA jest centralnym organem administracji rządowej $\left.{ }^{64}\right)$ i szerokie uprawnienia w zakresie zezwolenia na użytkowanie materiałów jądrowych, kontroli takiej działalności, zwłaszcza transportu takich materiałów oraz zapewnienia bezpieczeństwa jądrowego.

\subsection{Rozwój osadnictwa i procesy urbanizacyjne ${ }^{65}$ jako źródło procesów kreowania nowych zadań administracji}

W ewolucji cywilizacji ludzkiej szczególną rolę odgrywa osadnictwo. Można wręcz zaryzykować tezę, że dopiero osiadły tryb życia grup ludzi zapoczątkował współczesną cywilizację, jako że umożliwił powstanie rolnictwa i rzemiosła, które są jej kluczowymi przejawami. Powstawanie stałych osad wiązało się z koniecznością wznoszenia pierwszych w miarę trwałych konstrukcji schronienia, które z racji wcześniejszego koczowniczego trybu życia były zbędne, a wręcz niemożliwe. Początkowe dosyć spontanicznie wznoszone konstrukcje lokowane były głównie z powodów pragmatycznych (dogodność ukształtowania terenu, dostęp do materiału budowlanego, a przede wszystkim dostęp do wody), ale też liczebność tych osad w stosunku do wciąż niezagospodarowanej przestrzeni nie stwarzała żadnych

${ }^{62}$ Zob. ustawa z dnia 21 kwietnia 2005 roku o opłatach abonamentowych (Dz.U. z 2019 r. poz. 1801) wraz z jej aktami wykonawczymi, w tym rozporządzeniem Ministra Administracji i Cyfryzacji z dnia 10 września 2013 roku w sprawie kontroli wykonywania obowiązków związanych z opłatami abonamentowymi (Dz.U. poz. 1140).

${ }^{63}$ Ustawa z dnia 27 lutego 1982 roku o utworzeniu Polskiej Agencji Atomistyki (Dz.U. Nr 7, poz. 64).

${ }^{64}$ Zob. art. 109 ustawy z dnia 29 listopada 2000 roku — Prawo atomowe (Dz.U. z 2019 r. poz. 1792).

${ }^{65} \mathrm{~W}$ artykule urbanizacja jest ujmowana głównie w aspekcie przestrzennym, ale należy mieć na uwadze także aspekty demograficzny, ekonomiczny i socjologiczny. Zob. D. Szymańska, J. Biegańska, Fenomen urbanizacji i procesy z nim związane, „Studia Miejskie” 11, 2011. 
ograniczeń. Dopiero ich przekształcanie się w większe wsie ${ }^{66}$, a następnie w miasta zaczęło zmuszać do bardziej planowej zabudowy ${ }^{67}$. Zwłaszcza funkcje miejskie oddziaływały na plany zabudowy, bo lokowane były w nich siedziby organów władzy różnej rangi w strukturze państwa terytorialnego wraz z towarzyszącymi im obiektami militarnymi, obiekty świątynne i sepulkralne, obiekty handlowo-usługowe i wreszcie budynki mieszkalne. Determinowało to podziały terytorium miasta $\mathrm{w}$ związku z różnymi funkcjami — stąd pierwsze plany zabudowy, do których zalicza się schemat Hippodamosa z Miletu, wykorzystany przy budowie miast niemal w całym basenie Morza Śródziemnego (Miletu, Pireusu, Rodos) ${ }^{68}$, czy też plan Dinokratesa, na którym oparto budowę Aleksandrii ${ }^{69}$. O zakładaniu osad, a zwłaszcza miast, i ich planowej zabudowie decydowali władcy, czasami monarchowie, a czasami organy kolegialne, zatrudniano do tych przedsięwzięć ówczesnych architektów i budowniczych podlegających ścisłej kontroli organów sprawujących władzę. Choć nie zachowały się udokumentowane źródła ich zarządzeń, w literaturze urbanistycznej przywołuje się programy zabudowy na przykład Juliusza Cezara, a później jego następców, Augusta i Nerona ${ }^{70}$.

Po X wieku zaczynają się pojawiać pierwsze prawa lokacyjne miast, które poza stosunkami prawnymi między miastem a władcą feudalnym, a także ustrojem samego miasta ustalały zasady jego planowania i zabudowy (prawo walońskie, prawo lubeckie, prawo magdeburskie z jego średzką odmianą, prawo chełmińskie itp.), a około XV wieku rozpowszechniały się w miastach zakazy wznoszenia budynków z materiałów palnych, ale też zasada budowy wyłącznie za zezwoleniem władcy, zwłaszcza gdy budowla mogła odgrywać znaczenie obronne i militarne

66 Do dziś zachowały się założenia wsi, począwszy od wsi rozproszonych, po bardziej rozplanowane typu okolnicowego, owalnicowego, ulicówek, rzędówek, szeregówek, wielodrożnicowych, widlicowych i łańcuchówek w terenach górskich.

67 Najstarsze odkryte miasto, Çatal Hüyük w Anatolii (Turcja), pochodzi z okresu 8200-5500 lat p.n.e. Zajmowało owalny teren o wymiarach $450 \times 275 \mathrm{~m}$ i powierzchni około 13 ha. Znajdowało się w nim około 130-140 domów i aż 40 sanktuariów, przypuszczalnie zamieszkałych przez 5-10 tys. mieszkańców. Najstarszym do dziś zamieszkałym miastem jest Jerycho w Izraelu, którego początki sięgają 8000 lat p.n.e. Por. M. Kostrzewska, Miasta europejskie na przestrzeni dziejów. Wybrane przykłady, Gdańsk 2013, s. 5-6.

68 J. Słodczyk, Historia planowania i budowy miast, Opole 2012, s. 37-52.

69 P. Śleszyński, T. Markowski, A. Kowalewski, Kryzys gospodarki przestrzennej i urbanistyki, „Studia Komitetu Przestrzennego Zagospodarowania Kraju” 182. Studia nad chaosem przestrzennym, cz. 3. Synteza. Uwarunkowania, skutki i propozycje naprawy chaosu przestrzennego, 2018, s. 29-30.

70 M. Kostrzewska, op. cit., s. 39. August wprowadził regulacje dotyczące maksymalnej wysokości zabudowy ( $21 \mathrm{~m}$, w sytuacji gdy wznoszono wcześniej budowle sięgające $30 \mathrm{~m}$ ), a także podział Rzymu na 14 dzielnic i 256 kwartałów, a dla bezpieczeństwa ustanowił liczącą 7 tys. osób straż pożarną w mieście liczącym wówczas około 400 tys. mieszkańców zamieszkałych w około 47 tys. kamienic czynszowych i 1800 komfortowych willach arystokratów, na powierzchni około $800 \mathrm{~km}^{2}$; ibidem, s. 43. Zob. też C. Kunderewicz, Prawo budowlane starożytnego Rzymu, „Czasopismo Prawno-Historyczne" 1977, nr 2. 
(na przykład warowne zamki itp.). W okresie renesansu we Włoszech pojawiły się modele teoretyczne miasta idealnego, którymi kierowali się właściciele miast prywatnych (w Polsce przykładem jest Zamość), ale też władcy panujący na większych terytoriach. Tendencje te były kontynuowane w okresie baroku, gdy Ludwik XIV przenosił siedzibę do Wersalu, lecz także w późniejszym czasie, gdy w 1746 roku Ludwik XV ogłosił konkurs na przebudowę centrum Paryża, a w XIX wieku Robert Owen projektował swoje New Lanark, Ebenezer Howard zaś — koncepcję Garden City.

Dopiero jednak w XIX wieku zaczynają się pojawiać pierwsze regulacje prawne systematycznie określające zasady planowania zabudowy oraz projektowania budynków i prowadzenia prac budowlanych, a zatem pierwowzory dzisiejszych aktów prawa przestrzennego i budowlanego. Tym samym procesy urbanistyczne przestają być wynikiem kaprysu władcy połączonego z wizją bardziej lub mniej zdolnego projektanta, a stają się wynikiem stosowania norm prawa, które nakłada na istniejące lub specjalnie w tym celu tworzone organy administracji nowe zadania w stopniu o wiele bardziej uszczegółowionym i powszechnym dla całego państwa, w przeciwieństwie do lokalnych regulacji prawa lokacyjnego czy aktów przyjmowanych przez władze miejskie. Jednym z pierwszych w tym względzie była ustawa dotycząca warunków sanitarnych w Wielkiej Brytanii, która nie tylko ustanawiała centralny i lokalne urzędy zdrowia publicznego, lecz także wyposażała je w uprawnienia nakazowe $\mathrm{i}$ kontrolne $\mathrm{w}$ zakresie projektowania oraz przebudowy miast w celu zapewnienia bezpiecznych warunków życia ${ }^{71}$.

W tym samym czasie na ziemiach polskich władze zaborcze wprowadzają liczne regulacje dotyczące planowania miast ${ }^{72}$, w tym z takich powodów, jak na przykład wydzielanie rewirów dla ludności żydowskiej ${ }^{73}$ lub też ustalanie wa-

71 An Act of promoting the Public Health, 31 August 1848, CAP. LXIII, „London Gazette”, s. 721-784. Ciekawe są zwłaszcza przepisy dotyczące obowiązku zakładania kanalizacji ściekowej (art. XLI-XLVIII) i wyposażania budynków w instalacje kanalizacyjne (art. XLIX-LIV), projektowania lokali mieszkalnych w suterynach (art. XLVII), projektowania ulic i zarządzania nimi (art. LXVIII-LXXIII), organizacji miejsc rekreacji (art. LXXIV), zapewnienia dostępu do wody (art. LXXV-LXXVI), publicznych łaźni (art. LXXVII), organizacji miejsc przechowywania i pochówku zwłok (art. LXXXI-LXXIII). Zwraca też uwagę rozbudowany katalog rodzajów dróg w definicji drogi z art. II (s. 723): „The Word »Street« shall apply to and include any Highway [...], and any Road, public Bridge [...], Lane, Footway, Square, Court, Alley, Passage, [...]”.

72 Jako przykład może posłużyć postanowienie Namiestnika Królestwa Polskiego zamieszczone w Zbiorze Przepisów Administracyjnych Królestwa Polskiego 1866, cz. I, t. II z dnia 27 maja 1817 roku o rewizyi budynków, niebezpieczeństwem zawalenia się grożących i naprawieniu lub rozebraniu onych, dobrowolnie lub z urzędu (s. 329-333), która to rewizja jest swoistym pierwowzorem współczesnego nadzoru budowlanego z dnia 19 czerwca 1818 roku o zabudowaniu placów pustych po miastach (s. 335-337), decyzja z dnia 30 września 1820 roku zatwierdzająca przepisy Policyi budowniczej dla miast w Królestwie Polskim (s. 339-355).

${ }^{73} \mathrm{H}$. Bartoszewicz (Projekty rewirów dla ludności żydowskiej w miastach mazowieckich 1807-1830, „Rocznik Mazowiecki” 18, 2006, s. 104-120) poddał analizie kilkadziesiąt aktów różnej rangi (głównie dekretów) wydawanych przez rozmaite organy w dynamicznie zmieniającej się 
runków osadnictwa cudzoziemców ${ }^{74}$. Dopiero w drugiej połowie XIX wieku w zaborze pruskim ${ }^{75}$, austriackim ${ }^{76}$ i rosyjskim ${ }^{77}$ pojawiają się przepisy bliższe współczesnemu pojmowaniu zagospodarowania przestrzeni z licznymi zdaniami dla ówczesnych organów administracji o bardzo przecież zróżnicowanej strukturze. Po odzyskaniu niepodległości procesy urbanizacyjne w Polsce przebiegały już pod rządami ścisłych i licznych regulacji, począwszy od pierwszej — po protezowym utrzymywaniu przepisów z okresu zaborów — ustawy z 1925 roku $^{78}$, przez rozporządzenie z 1928 roku $^{79}$ i pierwsze powojenne dekrety, a następnie

sytuacji porozbiorowej, na podstawie których projektowano przebudowę niektórych miast lub jedynie wydzielanie owych rewirów (osiedli, dzielnic), w których wolno było zamieszkiwać ludności żydowskiej. Na ich podstawie organy władz miejskich zatwierdzały plany zabudowy. Osobnym przykładem jest postanowienie carskie z dnia 7 maja 1822 roku o urządzeniu mieszkań Żydów po miastach (Dz.Pr.Kr.P. z 1820 r. Nr 31, t. 7, s. 384-390).

74 Przykładowo P. Szkutnik (Sprowadzanie użytecznych cudzoziemców. Osadnicy w zachodniej części Królestwa Polskiego w pierwszej połowie XIX w. na przyktadzie przodków autora, „Kwartalnik Historii Kultury Materialnej” 61, 2013, nr 3, s. 409-410) podaje przykłady dekretów, między innymi z dnia 2 marca 1816 roku o osiedlaniu się w kraju użytecznych cudzoziemców, fabrykantów, rzemieślników i rolników. To na jego podstawie, dzięki rozporządzeniu z dnia 4 kwietnia 1819 roku, które rozciągało zasady projektowania nowych osad na ludność miejscową, Prezes Komisji Województwa Mazowieckiego otrzymał w 1821 roku akceptację dla rozbudowy pięciu miast, w tym nowej Łodzi - zob. M. Kostrzewska, op. cit., s. 133-134. O roli administracji państwa pruskiego w planowym osadnictwie zob. K.P. Woźniak, Niemieckie osadnictwo wiejskie między Prosna a Pilica $i$ Wisła od lat 70. XVII wieku do 1886 r. Proces i jego interpretacje, Łódź 2013, zwłaszcza rozdz. II. Osadnictwo w Prusach Poludniowych. Blaski i cienie kameralistyki na rubieżach państwa oraz rozdz. III i IV.

75 Ustawa dotycząca zakładania i zmiany ulic i placów w miastach i miejscowościach wiejskich z dnia 2 lipca 1875 roku (Zbiór Ustaw Królestwa Pruskiego, s. 561).

76 Dosyć liczna grupa ustaw w związku z poświęceniem ich konkretnym miejscowościom (Kraków w 1883 roku i Lwów w 1885 roku) poza kilkoma wyjątkami: ustawą z dnia 28 kwietnia 1882 roku zwierającą przepisy budowlane dla gmin miejskich (Dz.Ust. i Rozp.Kr. dla Kr.G. i L. z W. Ks.Kr. Nr 63 z 1883 r.), ustawą budowniczą dla znaczniejszych miejscowości w Królestwie Galicji i Lodomerii wraz z Wielkim Księstwem Krakowskim z dnia 4 kwietnia 1889 roku (Dz.Ust. i Rozp. Kr. dla Kr.G. i L. z W.Ks.Kr. Nr 31 z 1889 r.), ustawą budowniczą dla wsi i pomniejszych miejscowości w Królestwie Galicji i Lodomerii wraz z Wielkim Księstwem Krakowskim z dnia 13 października 1889 roku (Dz.Ust. i Rozp.Kr. dla Kr.G. i L. z W.Ks.Kr. Nr 133 z 1889 r.). Od 1897 roku przyjmowano ustawy nakazujące budowę kanalizacji domowej i łączenia jej z miejską kolejno dla miejscowości Białe (1897), Tarnopol (1908), Bochnia (1908), Nowy Sącz (1909) i Kraków (1914). K.W. Kumaniecki, Zarys austryackiego prawa budowlanego, Kraków 1914.

77 Ustawa budowlana (Zb. Praw Ces. Ros. Tom XII, cz. I 1909) wraz z rozporządzeniem z dnia 29 listopada 1916 roku dotyczącym sporządzania planów zabudowy (Dz.Rozp. dla Gen.Gub. Warsz. Nr 58) i rozporządzeniem budowlano-policyjnem dla wsi z dnia 20 listopada 1917 roku (Dz. Rozp. dla Gen.Gub.Warsz. Nr 99).

78 Ustawa z dnia 29 kwietnia 1925 roku o rozbudowie miast (Dz.U. Nr 51, poz. 346) zastąpiona rozporządzeniem Prezydenta RP z dnia 22 kwietnia 1927 roku o rozbudowie miast (Dz.U. z 1936 r. Nr 10, poz. 107).

79 Rozporządzenie z dnia 16 lutego 1928 roku o prawie budowlanym i zabudowie osiedli (Dz.U. z 1939 r. Nr 34, poz. 216). 
ustawy z 1961 roku $^{80}, 1984$ roku $^{81}, 1994$ roku $^{82}$, aż po obecnie obowiązującą ustawę z 2003 roku $^{83}$.

Każda kolejna regulacja rozbudowywała katalog zadań administracji publicznej ${ }^{84}$, ale też ich strukturę ${ }^{85}$, a w ostatnim dwudziestoleciu obserwujemy coraz częstsze wprowadzanie ustaw odnoszących się do szczególnych typów inwestycji $^{86}$. Przepisom o planowaniu przestrzennym od lat sześćdziesiątych towarzyszą odrębne już regulacje prawa budowlanego ${ }^{87}$, które także znacząco rozszerzyły

80 Ustawa z dnia 31 stycznia 1961 roku o planowaniu przestrzennym (Dz.U. z 1975 r. Nr 11, poz. 67).

81 Ustawa z dnia 12 lipca 1984 roku o planowaniu przestrzennym (Dz.U. z 1989 r. Nr 17, poz. 99).

82 Ustawa z dnia 7 lipca 1994 roku o zagospodarowaniu przestrzennym (Dz.U. z 1999 r. Nr 15, poz. 139).

83 Ustawa z dnia 27 marca 2003 roku o planowaniu i zagospodarowaniu przestrzennym (Dz.U. z 2018 r. poz. 1945).

${ }^{84}$ Doskonałym przykładem jest wprowadzenie do planowania przestrzennego narzędzi chroniących krajobraz, a zwłaszcza audytu krajobrazowego i reglamentacji umieszczania reklam w przestrzeni publicznej na mocy przepisów ustawy z dnia 24 kwietnia 2015 roku o zmianie niektórych ustaw w związku ze wzmocnieniem narzędzi ochrony krajobrazu (Dz.U. poz. 774) oraz narzędzi rewitalizacji obszarów zdegradowanych na mocy przepisów ustawy z dnia 9 października 2015 roku o rewitalizacji (Dz.U. z 2018 r. poz. 1398).

85 Można wspomnieć o istniejących w przeszłości organach planowania przestrzennego, jak Główny Urząd Planowania Przestrzennego oraz regionalne dyrekcje planowania przestrzennego z działu III dekretu z dnia 2 kwietnia 1946 roku o planowym zagospodarowaniu przestrzennym kraju (Dz.U. Nr 16, poz. 109), Komisja Planowania przy Radzie Ministrów i Komitet Budownictwa, Urbanistyki i Architektury z art. 5 ust. 1 ustawy z 1961 roku, Państwowa Rada Gospodarki Przestrzennej z art. 9 ustawy z 1984 roku czy Główna Komisja Urbanistyczno-Architektoniczna i wojewódzka komisja z art. 5 ust. 2-4 ustaw z 1994 roku. Także obecnie liczba organów jest imponująca i ciągle rośnie, bo obok organów właściwych w zakresie planowania przestrzennego w zależności od rodzaju planu (od Rady Ministrów, przez sejmik województwa, po radę gminy), występują ciała stałe (na przykład komisje urbanistyczno-budowlane) i doraźne (na przykład Komitet Rewitalizacyjny).

${ }^{86}$ Zjawisko jest w doktrynie przedmiotem bardzo zróżnicowanych ocen, na przykład T. Bąkowski, K. Kaszubowski, Regulacje tak zwanych specustaw inwestycyjnych wobec samodzielności i władztwa planistycznego gminy, [w:] Przestrzeń i nieruchomość jako przedmiot prawa administracyjnego. Publiczne prawo rzeczowe, red. I. Niżnik-Dobosz, Warszawa 2012, s. 263-276, ale też liczba tych regulacji jest znacząca i stale wzrasta: ustawa z dnia 9 sierpnia 2019 roku o inwestycjach w zakresie budowy portów zewnętrznych (Dz.U. poz. 1924), ustawa z dnia 19 lipca 2019 roku o inwestycjach w zakresie budowy Muzeum Westerplatte i Wojny 1939 — Oddziału Muzeum II Wojny Światowej w Gdańsku (Dz.U. poz. 1589), ustawa z dnia 22 lutego 2019 roku o przygotowaniu i realizacji strategicznych inwestycji w sektorze naftowym (Dz.U. poz. 630), ustawa z dnia 5 lipca 2018 roku o ułatwieniach w przygotowaniu i realizacji inwestycji mieszkaniowych oraz inwestycji towarzyszących (Dz.U. z 2020 r. poz. 219), ustawa z dnia 10 maja 2018 roku o Centralnym Porcie Komunikacyjnym (Dz.U. z 2020 r. poz. 234). Istotnie stawia to pod znakiem zapytania systemowość prawa zagospodarowania przestrzennego i przewidzianych w nim zasad lokalizacji inwestycji celu publicznego.

87 Pierwszą samodzielną w stosunku do dotychczas łącznej z planowaniem przestrzennym była ustawa z dnia 31 stycznia 1961 roku (Dz.U. Nr 7, poz. 46) zastąpiona ustawą z dnia 24 października 1974 roku (Dz.U. Nr 38, poz. 229), a ostatecznie obecnie obowiązującą ustawą z dnia 7 lipca 1994 roku (Dz.U. z 2019 r. poz. 1186).

Prawo 331, 2020

(C) for this edition by CNS 
katalog zadań, ale też rozbudowały strukturę organów właściwych osobno w zakresie architektoniczno-budowlanym, a osobno w zakresie nadzoru budowlanego. Jeśli powiązać je z zadaniami w zakresie zbiorowego zaopatrzenia w wodę i odbierania ścieków ${ }^{88}$, a także gospodarowania odpadami ${ }^{89}$, zagadnieniami ochrony środowiska, a w tym tak typowych dla współczesnych skutków urbanizacji jak ochrona przed zanieczyszczeniem powietrza i hałasem ${ }^{90}$, to skala i złożoność tych zadań wydaje się jeszcze dobitniej uświadamiać, jak bardzo administracja publiczna rozprzestrzenia się na wszelkie przejawy życia społecznego.

\section{Zakończenie}

Wspomniany Jan Boć przywoływał też wiele innych czynników wywołujących zmiany, a w tym rozrost administracji publicznej. Choć nie objąłem ich prowadzoną tu analizą, to niezaprzeczalnie pojawiały się w przeszłości doktryny prawno-polityczne, na których sprawujący władzę często opierali swoje koncepcje budowania ustroju państwa (choćby doktryny faszystowskie i komunistyczne), wyposażając ich administrację w nowe funkcje i zadania. Podobnie wielkie wydarzenia historyczne, które w gwałtowny sposób wywoływały zmiany na politycznych mapach — wojny (jak choćby wojny napoleońskie, które doprowadziły najpierw do odzyskanej państwowości w postaci Księstwa Warszawskiego z nowym ustrojem administracji, a następnie jej szybkiego upadku; I wojna światowa, której rozstrzygnięciom zawdzięczamy ponowne odzyskanie niepodległości, przerwane wybuchem II wojny, której zakończenie nie tylko wpłynęło na wytyczenie nowych granic państwa, ale spowodowało poddanie wpływowi sowieckiej koncepcji administracji państwowej) i rewolucje (ta francuska pozwoliła uwolnić się od monarchii absolutnej i podjąć wieloletni trud budowania kolejnych republik z coraz to nowocześniejszą administracją, sowiecka zaś zamieniła przestarzałe państwo carskie w obszar tragicznego eksperymentu budowania nierealnego państwa komunistycznego z administracją służącą przemocy i terrorowi). Wreszcie bez wątpienia na przemiany współczesnej administracji wywiera wpływ rozwój nauki, zwłaszcza nauk administracyjnych i proponowanych w nich nowych koncepcji administrowania, które w miejsce klasycznych form władczego działania stosują działania niewładcze, oparte raczej na współadministrowaniu z udziałem

88 Ustawa z dnia 7 czerwca 2001 roku o zbiorowym zaopatrzeniu w wodę i zbiorowym odprowadzaniu ścieków (Dz.U. z 2019 r. poz. 1437).

89 Ustawa z dnia 14 grudnia 2012 roku o odpadach (Dz.U. z 2019 r. poz. 701) i ustawa z dnia 13 września 1996 roku o utrzymaniu porządku i czystości w gminach (Dz.U. z 2019 r. poz. 2010).

90 Ustawa z dnia 27 kwietnia 2001 roku — Prawo ochrony środowiska (Dz.U. z 2019 r. poz. 1396). 
samych administrowanych ${ }^{91}$. Wypada też zaznaczyć ogromny wpływ ekonomii i wszelkich procesów społecznych z niej wynikających, przede wszystkim w kierunku globalizacji, która zmusza administrację do sprostania jej wyzwaniom ${ }^{92}$.

Przeprowadzona w artykule analiza rozrostu zjawiska administracji jako naturalnego procesu towarzyszącego rozwojowi cywilizacyjnemu jest istotnym przyczynkiem do uzasadnienia tezy o niepomijalności administracji publicznej. Należy zważyć, że tytułowa dyspersja administracji nie jest celem samym w sobie, a wyłącznie wynikiem procesów zachodzących w otoczeniu administracji.

\section{Bibliografia}

Bartoszewicz H., Projekty rewirów dla ludności żydowskiej w miastach mazowieckich 1807-1830, „Rocznik Mazowiecki” 18, 2006.

Bąkowski T., Kaszubowski K., Regulacje tak zwanych specustaw inwestycyjnych wobec samodzielności i władztwa planistycznego gminy, [w:] Przestrzeń i nieruchomość jako przedmiot prawa administracyjnego. Publiczne prawo rzeczowe, red. I. Niżnik-Dobosz, Warszawa 2012.

Boć J., Uwarunkowania rozwoju administracji publicznej, [w:] Administracja publiczna, red. J. Boć, Wrocław 2003, rozdz. II.

Ciapała S., Zielonka T., Kmiecik-Wróbel J., Metody zapobiegania nielegalnej dyspersji turystów i związanej z niq erozji gleby w Tatrzańskim Parku Narodowym, „Folia Turistica. Turystyka i ekologia” 2010, nr 22.

Czyżowicz, W., Woźniczko M., Cło i celnicy w historii. Struktury i mechanizmy działania, Warszawa 2012.

Galewski T., Czynniki wpływające na dyspersję cen na e-rynkach, „Konsumpcja i Rozwój” 2015, nr $1(10)$.

Gochnat C., Repertorium sämtlicher vom Jahre 1800 bis einschließlich 1845 für die Provinz NiederÖsterreich erlassenen politischen und Justiz Gesetze und Verordnungen. In alphabetisch-chronologischer Ordnung, t. 1, Wien 1846.

Helliinger B., Die geschichtliche Entwicklung der Dampfkesselaufsicht in Preußen, [w:] Beiträge zur Geschichte der Technik und Industrie, red. C. Matchoss, „Jahrbuch der Vereines Deutscher Ingenieure" 7, 1916.

Izdebski H., Kulesza M., Administracja publiczna. Zagadnienia ogólne, Warszawa 1999.

Jaworski W.L., Nauka prawa administracyjnego. Zagadnienia ogólne, Warszawa 1924.

Korczak J., Co-administering as policy in the administrative reform. Reasons for reforms of public administration and types these reforms, [w:] Administrative Law and Science in the European Context, t. 1, red. J. Sługocki, Szczecin 2015.

91 Twórcą koncepcji działań niewładczych był Tadeusz Kuta; zob. J. Korczak, Koncepcja działań niewładczych Profesora Tadeusza Kuty. Z dorobku wrocławskiej szkoty administratywistycznej, [w:] Stan i kierunki rozwoju nauk administracyjnych, red. J. Boć, A. Błaś, Wrocław 2014, s. 152-172; idem, Co-administering as policy in the administrative reform. Reasons for reforms of public administration and types these reforms, [w:] Administrative Law and Science in the European Context, t. 1, red. J. Sługocki, Szczecin 2015, s. 63-74.

92 Zob. M. Magdziarczyk, Administracja publiczna wobec procesów globalizacji i europeiza$c j i$, „Zeszyty Naukowe Wyższej Szkoły Bankowej we Wrocławiu” 2011, nr 26, s. 151-167. 
Korczak J., Koncepcja działań niewładczych Profesora Tadeusza Kuty. Z dorobku wrocławskiej szkoty administratywistycznej, [w:] Stan i kierunki rozwoju nauk administracyjnych, red. J. Boć, A. Błaś, Wrocław 2014.

Korczak J., O zwiąkach administracji publicznej ze statystyka publiczna na przykładzie samorzadu terytorialnego, [w:] Statystyka publiczna w stużbie samorzadu terytorialnego. Konferencja naukowa Wrocław 7-8 marca 2011 r., red. S. Kamiński, E. Mazurek („Biblioteka Wiadomości Statystycznych", t. 65), Warszawa 2011.

Korczak J., W kwestii reform konsolidacyjnych w polskim samorządzie terytorialnym, [w:] Dziesięć lat polskich doświadczeń w Unii Europejskiej. Problemy prawnoadministracyjne, t. 2, red. J. Sługocki, Wrocław 2014.

Kostrzewska M., Miasta europejskie na przestrzeni dziejów. Wybrane przykłady, Gdańsk 2013.

Kumaniecki K.W., Zarys austryackiego prawa budowlanego, Kraków 1914.

Kunderewicz C., Prawo budowlane starożytnego Rzymu, „Czasopismo Prawno-Historyczne” 1977, $\mathrm{nr} 2$.

Kuś A., Cło i postępowanie celne w Polsce przedrozbiorowej, „Rocznik Nauk Prawnych” 2, 2002, z. 1 .

Longchamps F,. Założenia nauki administracji, Wrocław 1991.

Magdziarczyk M., Administracja publiczna wobec procesów globalizacji i europeizacji, „Zeszyty Naukowe Wyższej Szkoły Bankowej we Wrocławiu" 2011, nr 26.

Rybczyński S., Kierownictwo administracji niemieckiej jako organizacja przestępcza w GG, „Demokratyczny Przegląd Prawniczy" 3, 1947, nr 4.

Rys R., Správni vĕda, nauka o správnich reformach a teorie reform, „Časopis pro právni vědu a praxi” $18,2010, \mathrm{nr} 2$.

Słodczyk J., Historia planowania i budowy miast, Opole 2012.

Stawecki T., Rejestry publiczne. Funkcje instytucji, Warszawa 2005.

Szkutnik P., Sprowadzanie użytecznych cudzoziemców. Osadnicy w zachodniej części Królestwa Polskiego w pierwszej połowie XIX w. na przykładzie przodków autora, „Kwartalnik Historii Kultury Materialnej” 61, 2013, nr 3.

Szydło M., Zezwolenie telekomunikacyjne, „Kwartalnik Prawa Publicznego” 2003, nr 2.

Szymańska D., Biegańska J., Fenomen urbanizacji i procesy z nim zwiazane, „Studia Miejskie” 11, 2011.

Śleszyński P., Markowski T., Kowalewski A., Kryzys gospodarki przestrzennej i urbanistyki, „Studia Komitetu Przestrzennego Zagospodarowania Kraju" 182. Studia nad chaosem przestrzennym, cz. 3. Synteza. Uwarunkowania, skutki i propozycje naprawy chaosu przestrzennego, 2018.

Špaček D., Public administration reform, http://is.muni.cz/el/1456/podzim2006/PVTRPS/um/Public_Administration_Reform.pdf.

Wimmer $\bar{N}$., Reform of public administration in Austria. Activities and perspectives, „Hrvatska Javna Uprawa” 2007, nr 3.

Woźniak K.P., Niemieckie osadnictwo wiejskie między Prosna a Pilica i Wista od lat 70. XVII wieku do 1886 r. Proces i jego interpretacje, Łódź 2013. 


\section{Dispersion of administration as a reason for non-negligibility of public administration}

\section{Summary}

The article presents a view of the unlimited growth of the administrative phenomenon influenced by civilizational transformations. Its various causes and shaping factors will be presented, as a result of which the administration receives new tasks to be carried out. As a consequence of the growth of tasks, its structures are being edified, but also by transformations in the form of action. As will be shown, the dispersion process is objective and is not the result of the administration itself, but of external factor.

Keywords: public administration, administrative phenomenon, dispersion, border administrative law. 